\title{
Universitetet i Bergen
}

www.uib.no/info/dr_grad/

Lars Fjetland, ph.d. Endovascular stroke treatment at Stavanger University Hospital. Utgår fra Klinisk institutt 1. Disputas 8.5. 2015.

Bedømmelseskomité: John Hald, Oslo universitetssykehus, Rolf Salvesen, Universitetet i Tromsø, og Marit Grønning, Universitetet i Bergen.

Veiledere: Martin Kurz, Jan Petter Larsen, Kathinka Dæhli Kurz og Sumit Roy.

Solbjørg Makalani Myrtveit, ph.d. Risk factors for development and maintenance of chronic whiplash. Utgår fra Klinisk institutt 2. Disputas 13.5. 2015.
Bedømmelseskomité: Trudie Chalder, King's College, London, Storbritannia, Ragnhild Elise Ørstavik, Nasjonalt folkehelseinstitutt, og Jon Hardie, Universitetet i Bergen.

Veiledere: Børge Sivertsen, Ingvard Wilhelmsen og Jens Christoffer Skogen.

Ellen Berget, ph.d. Lymphoma niches and microenvironment in the pathogensis, prognosis and treatment of B-cell lymphomas. Utgår fra Klinisk institutt 1. Disputas 27.5. 2015.

Bedømmelseskomité: Klaus Beiske, Oslo universitetssykehus, Marianne Brodtkorb, Oslo universitetssykehus, og Olav Mella, Universitetet i Bergen.

Veileder: Olav Karsten Vintermyr.

\section{Priser for klinisk psykiatrisk forskning på barn og ungdom}
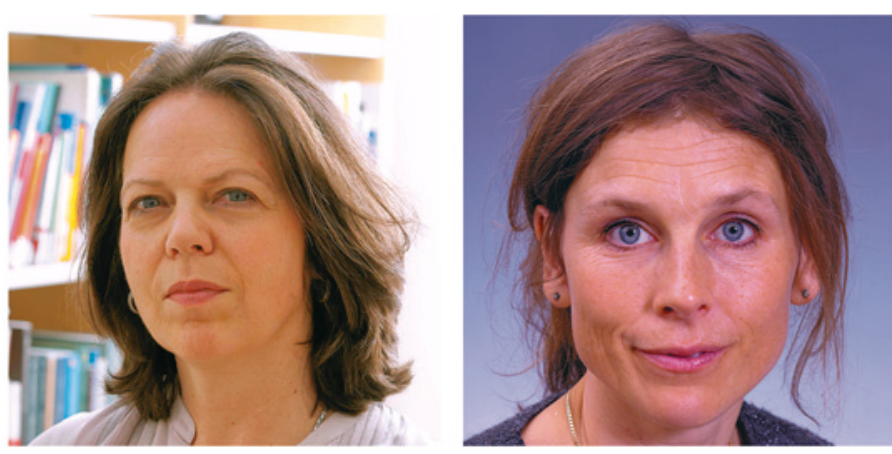

Marianne Jakobsen (til venstre) og Synne Øien Stensland. Foto: Lars Sørli

Marianne Jakobsen (f. 1958) og Synne Øien Stensland (f. 1974), begge forskere ved Nasjonalt kunnskapssenter om vold og traumatisk stress (NKVTS), har mottatt hver sin pris fra Solveig og Johan P. Sommers stiftelse til fremme av klinisk psykiatrisk forskning. Prisene får de for artikler publisert i 2014.

Jakobsens artikkel Prevalence of psychiatric disorders among unaccompanied asylum-seeking adolescents in Norway ble publisert i Clinical Practice \& Epidemiology in Mental Health, Stenslands artikkel Recurrent headache and interpersonal violence in ado- lescence: the roles of psychological distress, loneliness and family cohesion: the HUNT study ble publisert i The Journal of Headache and Pain.

Begge de prisbelønte forskerne er tidlig i sin forskerkarriere, og stiftelsen tildelte dem prisene $\mathrm{i}$ håp om å stimulere til fortsatt klinisk psykiatrisk forskning.

\section{Gunn Marit Seberg}

Tidsskriftet

\section{Leger stiller til valg som ordførerkandidater}

Tidsskriftet er blitt gjort oppmerksom på en liten kuriositet i høstens kommunevalg i Porsgrunn, nemlig at tre av ordførerkandidatene som er nominert på topp og stiller til valg er utdannet leger.

Ottar Berg (f. 1965), overlege og spesialist i fysikalsk medisin og rehabilitering ved Sykehuset Telemark, avdeling Porsgrunn, stiller til valg som ordfører for Miljøpartiet De Grønne, Robin Martin Kåss (f. 1977), lege og tidligere statssekretær i Jens Stoltenbergs andre regjering i Helse- og omsorgsdepartementet, bosatt i Porsgrunn, er ordførerkandidat for Porsgrunn Arbeiderparti, mens Esben Storvand (f. 1972), allmennpraktiserende fastlege ved Søsterhjemmet Medisinsk Senter i Porsgrunn, er Porsgrunn Høyres ordførerkandidat.

Tidsskriftet ønsker alle de tre lykke til med valget!

\section{Gunn Marit Seberg}

Tidsskriftet 